\section{An Overview On Social Innovation Research: Guiding Future Studies}

\author{
Manuela Rösing Agostini ${ }^{\dagger}$ \\ Instituto Federal do Rio Grande do Sul \\ Luciana Marques Vieira ${ }^{\Omega}$ \\ UNISINOS \\ Rosana da Rosa Portella Tondolo ${ }^{¥}$ \\ Universidade Federal de Pelotas \\ Vilmar Antonio Gonçalves Tondolo* \\ Universidade Federal do Rio Grande
}

\section{ABSTRACT}

Social innovation research has been increasing over the last decades in many countries and fields of study. This study understands social innovation (SI) as a way to mitigate social problems, resulting in new or improved solution for a specific community. This paper analyzes the research in the field of social innovation in the business management area, understanding its antecedents and trends. Therefore, the main goal of this paper is to propose a framework to guide further research in social innovation. Through a systematic literature review, the paper offers a preliminary framework with sub-themes of interest, possible contexts and actors involved in social innovation initiatives. The antecedents showed that the SI since the first concepts presents issues related to social change and has evolved to understand the relationships between different actors, between institutions and the social context where it is inserted. The trends link the SI to areas such as institutional theory; social movements theory; power and multi-actors perspective.

Keywords: Social innovation; Social problems; Literature review; Research framework.

\section{INTRODUCTION}

Debates for possible solutions to social problems are increasingly present in the discourse of social actors: groups of individuals, businesses, government, community, nonprofit organizations and academia. In this context, one may observe that at the global and national level, a search to find alternatives for solving economic crises or historical regional situations is underway.

In the Brazilian context, clearly recognized as a country whose socioeconomic development induced a context of regional disparities, the government, through the Ministry of Social Integration, set up a program to reduce regional inequalities and enable the potential development of regions. One of the Brazilian government's objectives is to encourage the exploitation of subregional potential arising from the magnificent diversity socioeconomic, environmental and cultural development (BRAZIL, 2012).
Corresponding author:

† Instituto Federal do Rio Grande do Sul.

E-mail: manuela.agostini@sertao.ifrs.

edu.br

$\Omega$ UNISINOS.

E-mail:1mvieira@unisinos.br

¥ Faculdade de Administração e de

Turismo da Universidade Federal de

Pelotas - UFPEL.

E-mail: rosanatondolo@gmail.com

* Instituto de Ciências Econômicas,

Administrativas e Contábeis da Universi-

dade Federal do Rio Grande - FURG.

E-mail:vtondolo@gmail.com

Received: 09/29/2015.

Revised: 02/10/2016.

Accepted: 03/21/2016

Published Online: 02/01/2017. 
Globally, in a post-recession economic scenario since 2008, much information presages the difficulties that many communities have been facing. In this context, numerous discussions on ways to solve such situations may be identified, the main proposal being to promote entrepreneurship and corporate citizenship values among students in the educational training process, complementing the standard curriculum with practical lessons that greatly stimulate entrepreneurship and social innovation (JENNER, 2012; SMITH; WOODWORTH, 2012).

Therefore, both international and Brazilian context there is a growing interest in research on the topic of social innovation based on the necessity of finding alternative ways for solving social problems which address regional differences and pay attention to the expectations of society. Thus, the main goal of this paper is to propose a framework to guide research in social innovation.

In order to achieve this goal, we carried out four steps: (1) to search for studies in databases on social innovation issues, analyzing the journals, year of publication, countries and institutions that published regularly the issue, to analyze the antecedents of SI; (2) to identify which methodologies are used by researchers in the field; (3) to identify the main objectives and results of a sample of papers in the area; and (4) to raise sub-themes to be studied in a future research agenda on social innovation, therefore identifying the main trends.

Social innovation, in turn, is analyzed at the level of social practice in order to better meet the emerging needs and problems of the social environment to which a social organization belongs, since this practice should be socially accepted and widespread. Thus, the collective unit learns, invents and puts into practice new rules for the social game of cooperation and conflict, acquiring in the process a cognitive and rational learning, developing new capabilities within a social organization (HOWALDT; SCHWARZ, 2010).

In this sense, this research is justified for social and academic reasons. Regarding social issues, we believe that social innovation is one of the routes to be followed in order to ensure a more just, egalitarian and zealous society for the rights and essential guarantees of citizens. By doing this study on social innovation, we intended somehow to contribute to social organizations.

Regarding the theoretical contribution, this study adds to the view of social innovation as a new and independent object of management science, helping to tailor its consolidation and systematization. Silva and Maurer (2014) points out that in the field of management, studies in innovation are usually seeing innovation in products or processes. However, internationally the concept of social innovation is already being used by groups of researchers who seek to find solutions for human needs. On the other hand, in Brazil, this kind of studies is emerging, especially in the area of management. These studies could be applied in order to solve out social problems of this country as other emerging and developing countries.

\section{SOCIAL INNOVATION}

Different authors define innovation as a creative process in the implementation of a new idea. It can be identified in products, processes, markets or organizational models. Drucker (2002) defines innovation as a tool used by entrepreneurs to exploit a change as an opportunity for a different business or a different service.

Further, in an established concept, the Oslo Manual (1997), which is one of the documents prepared by the Organization for Economic Cooperation and Development (OECD), one of the main collections on the use of data in innovative activities, discusses innovation as "...the implementation of a product (good or service) new or significantly improved, or a process, or a new marketing method, or a new organizational method in business practices, workplace organization or external relations." That definition clearly identifies the four 
BBR

14,4

dimensions of innovation: product innovation, process, marketing and organizational method. In addition, social innovation, led by corporations, arises as response to pressure from organizational stakeholders (individual, organizational, national, and transnational) (GOPALDAS, 2015).

For Schumpeter (1985), innovation may be the supplier of extraordinary profits, as it occurs in a continuous creative destruction process in which innovation generates monopoly, which gives rise to profits, which attracts imitators to a return of the normal state, leading to cycle repetition.

One may realize that the concepts have similarities and complementarities among them, in which the dimensions and characteristics of innovation that are regarded as prevalent in each concept definition may be identified.

Analyzing the concepts of innovation and identifying the need for their relationship with economic development theory, innovation may be observed as not necessarily linked only to commercial activity, although much of the existing literature shapes innovation in the context of industries. The Oslo Manual (1997, p. 22) states that "innovation can occur in any sector of the economy, including government services such as health and education."

Taken in this way, social innovation should be approached through a new lens. Farfus (2008, p. 36) considers the current cultural and business systems to be failing to meet social demands, allowing the emergence of movements and initiatives to reduce social gaps experienced in different realities. Thus, the same author emphasizes "the design of new strategies is a necessary condition for overcoming the challenges of post-modern society, considered by many scholars as a moment of historical transition. One of the strategies to overcome the challenges posed is the concept of social innovation". In addition, social innovation is driven by social entrepreneurs (BHATT; ALTINAY, 2013).

O'Byrne et al. (2013, p. 54) defined social innovation as the "successful implementation of activities, such as ideas, practices, or objects, through new collaborations and partnerships, in ways that positively impact society by improving the delivery of public services." Gaps in public services that involved quality and quantity of service have stimulated the emergence of global social innovations for base-of-the-pyramid markets (VARADARAJAN, 2014).

In this sense, Howaldt and Schwarz (2010) argue that the Schumpeterian theory does not focus solely on technical innovation but also on the innovation process and underscores the need for social innovation to occur in the economic arena as well as in the culture, politics and way of life of a society in order to ensure the economic efficiency of technical innovations.

Silva (2012) identifies studies in the literature on social innovation and its diffusion, noting that there is no consensus on the definition of the term. However, he states that the concept has multiplied in the world, especially in the United States, Canada, Europe and Brazil. In the United States, universities such as Stanford, Harvard and Brown formed study groups to research the topic. In Canada, one of the main groups for social innovation studies was established, the Centre de Recherche Sur Les Innovations Sociales (CRISIS). In Europe, INSEAD, the University of Cambridge and projects like EMUDE such as ISESS conduct research and are involved in social actions. In Brazil, the work of the Institute of Social Technology (ITS) stands out.

Similarly, Bignetti (2011) identifies social innovation as having an extensive range of approaches, methodologies and practices, which has become considered a consistent field of knowledge. The author also concludes that studies of social innovations differ from studies of technological innovations, and this area, social innovation and it needs new specific approaches and methodologies. The author also points out that many different notions or concepts on the subject exist with three units of analysis for social innovation: individual, organizations and movements. In this view, Table 1 presents a compilation of the different concepts and approaches of social innovation. 
Table 1. Social Innovation Concepts

\begin{tabular}{|c|c|}
\hline \multicolumn{2}{|r|}{ Social Innovation Concepts } \\
\hline Taylor (1970) & $\begin{array}{l}\text { Social innovation as the search for answers to social needs through the introduction } \\
\text { of a social invention, i.e., a "new way of doing things" a new social organisation. }\end{array}$ \\
\hline Cloutier (2003) & $\begin{array}{l}\text { Social innovation as a new response to an unfavorable social situation, which seeks the } \\
\text { well being of individuals and/or communities through action and sustainable change. }\end{array}$ \\
\hline Rodrigues (2006) & $\begin{array}{l}\text { Social innovations can occur intentionally or emerge from a process of social change } \\
\text { without prior planning; and can occur at three levels: social actors, organizations } \\
\text { and institutions. }\end{array}$ \\
\hline Mulgan et al. (2007) & $\begin{array}{l}\text { Innovative activities and services that are motivated by the objective of meeting a } \\
\text { social need and that are predominantly developed and diffused through organizations } \\
\text { whose main objectives are social. }\end{array}$ \\
\hline Bignetti (2011) & $\begin{array}{l}\text { Social innovation is the result of knowledge applied to social needs through } \\
\text { participation and cooperation of all stakeholders, creating new and lasting solutions } \\
\text { for social groups, communities and society in general. }\end{array}$ \\
\hline $\begin{array}{l}\text { Centre For Social } \\
\text { Innovation (2014) }\end{array}$ & $\begin{array}{l}\text { Social innovation refers to the creation, development, adoption and integration of } \\
\text { new concepts and practices that put people and the planet first. [...] Solve social, } \\
\text { cultural, economic and environmental issues. [...] Are changing systems - they have } \\
\text { permanently altered the perceptions, behaviors and structures that previously gave } \\
\text { rise to these challenges. [...] Social innovations come from individuals, groups or } \\
\text { organizations, and can take place in the sectors for-profit, nonprofit and public sector. }\end{array}$ \\
\hline Crises (2014) & $\begin{array}{l}\text { Social innovation is a process initiated by social actors to respond to a desire, a need, } \\
\text { to find a solution or to seize an opportunity of action to change social relations, to } \\
\text { transform a frame or propose new cultural orientations to improve the quality and } \\
\text { community living conditions. }\end{array}$ \\
\hline TRANSIT (2015) & $\begin{array}{l}\text { Transformative Social Innovation, as "change in social relations, involving new } \\
\text { ways of doing, organizing, framing and/or knowing, which challenges, alters and/ } \\
\text { or replaces dominant institutions/structures in a specific social context". }\end{array}$ \\
\hline
\end{tabular}

Source: Research Data These authors, in different stages of the evolution of this concept, show a latent concern for social change. The concept of Taylor, dated from 1970, addresses the SI as a new form of social organization, while Cloutier (2003) suggests an evolved concept for an innovative response that causes a sustainable change. In both concepts, the concern about change in society is visible, but they do not determine who will make this change.

In another study, Tardif and Harrison (2005) identified at least five main definitions for the concept of social innovation that leads to social change as follows: 1) novelty and character of innovation, 2) objective of innovation, 3) innovation process, 4) relationship between actors and structures, and 5) restrictions on innovation. Thus, these authors adapted the terminology and proposed, based on the analysis of the papers, five dimensions of social innovation, namely transformation, innovative character, innovation, actors and processes.

Evolving the concept, Mulgan et al. (2007) and Rodrigues (2006) show that the change process involves different actors. The involvement of social organizations also appears as an important factor in the evolution of the concept, as the SI is an alternative to the development of communities, but the changes should happen by the community and not only by external actions.

Discussing this characteristic of the concept of SI is critical to understand the transformative logic of SI. As an example of a new trend to the concept, an European research group called TRANSIT, has proposed the term Transformative Social Innovation (TRANSIT, 2015). In this new perspective, it is essential to understand that social innovation should become a reality where this is adopted. So, the social context in which the SI is 
BBR

14,4

adopted should be interpreted and transformations in this context must be understood. In this perspective, modern theoretical approaches have been adopted to understand this phenomenon, such as: Theory on Transformative Change; Social practice theory; power and multi-actor perspective; narratives approaches; institutional theory, institutional logics and institutional entrepreneurship; and, structuration theory.

These new areas of study in social innovation show that there is a concern of scholars for the evolution of the field. New relationships should be discussed with theoretical bases which are not customarily associated with this issue, and new methods can be adopted to understand the field.

As an example of this evolution by new theoretical relationships, Cajaiba-Santana (2014) sets out a new way to understand how social innovation plays as a source of social change, and it seeks closer ties with two theories. First, it analyzes the Institutional Theory "to argue that social innovation is always related to collective social action aiming at social change. The institutional perspective sees social innovation as a result of the exchanges and application of knowledge and resources by agents mobilized through legitimization activities". The second theory analyzed is the Structuration Theory "to describe how social innovation is created as a transformative force through the inter relationship between agents, institutional structures, and social systems".

In sum, we realize that new studies are emerging to enhance and improve the field, looking for more robust theories foundation for understanding the phenomenal studied in SI and thus seek improvements that contribute to a theoretical consolidation.

Moreover, the principles of social participation are closely related to the development of human evolution, and social innovation becomes an alternative to minimizing social gaps. In this perspective, the practice of social innovation may generate local development and may be focused towards learning and collective construction. Accordingly, social innovation may leverage social capital (BHATT; ALTINAY, 2013)

\section{RESEARCH METHOD}

Social innovation, as previously reported, has attracted attention from researchers in many areas. This finding suggests a need to generate studies aiming to develop a better understanding of the trajectory of this research stream, as well as a need to analyze the methodologies that have been used. According to Bento (2012), the aim of this kind of study is to identify topics for future research. We followed this authors' suggestions as follows: a) identification of key-words; b) review of secondary sources (summarized in Table 1 in the previous section); c) search of primary sources and finally d), critical reading to sum up in the paper.

In order to accomplish our purpose, we carried out an analysis of previous literature in order to propose a framework to guide further studies specifically in the business management area. The study started with a search for papers in international databases given a specific period of a time. We present the selection criteria for papers below.

The database used was the Web of Knowledge database platform bibliographic reference, produced by the Institute for Scientific Information (ISI). The platform consists of several reference databases such as Web of Science, Current Contents Connect, the Derwent Innovations Index (Patent), and other web resources such as the Journal Citation Report, Essential Science Indicators, Scientific WebPlus, BiologyBrowser, and ResearcherID, among others, covering thousands of periodicals in several areas of interest: science, social sciences, arts and humanities. The choice was also influenced by the fact that this database has tools that assist in the identification of citation indexes, enabling a more detailed analysis of historical article citations, including the most relevant journals, impact factor identification and direct links to other analysis tools (WEB OF KNOWLEDGE, 2013). 
The search was conducted in July 2013, being refined as follows:

- Key-word: "social innovation"; a total of 275 results were found;

- In the document type refinement, only papers was chosen, selecting 159 results;

- In one more refinement in the categories of Web of Science, we opted for the areas of "management" and "business" because they are to the search area, and the result was 35 papers;

- We opted for more current studies, and the analysis period was set from 2006 to 2013, resulting in 29 papers;

- It is important to note that the database utilized does not provide access to the full papers. They had to be extracted from another database. Therefore, in order to get the full papers, we used the databases EBSCO Host and Google Scholar. At this stage, 23 papers were found with full access. Thus, for analysis of general data on publications in the field we used 29 papers, but to analyze the methodologies used and contributions of the papers, the sample was limited to the 23 full-text papers available;

- The selected papers base were analyzed using a categorization, which addressed four aspects: (1) analysis of the journals, publication year, countries and institutions that publish more often on the subject, (2) identification of the methodologies used by researchers on the subject, (3) identification of the main objectives and results of the sample of papers in subject, and (4) provision of a framework proposal for research on social innovation;

- The analysis was performed using the criteria for classification proposed by Caldas, Tonelli and Lacombe (2002), which classified the methodological profile of the papers as follows. Papers may be (1) Theoretical; (2) Empirical; or, (3) Theoretical and empirical:

- If the paper is classified as (1) Theoretical, the authors seek to identify four characteristics, based on forums from the Academy of Management Review (1989) and Administrative Science Quarterly (1995): (1.1) theoretical essay on existent theory; (1.2) theoretical essay of current theory systematization; (1.3) theoretical essay that builds or proposes a concept or construct; and (1.4) theoretical essay that builds or proposes a theory;

- If the paper is (2) empirical or (3) theoretical and empirical, it can be classified, according to Creswell (1998), as: (2.1) qualitative; (2.2) quantitative; (2.3) survey; or (2.4) hypothetical-deductive method;

- If the paper is (2.1) qualitative, it may be classified as a singular case or multiple case study (one or multiple objects).

\section{DATA ANALYSIS}

Remarkable ranges of journals publish on the topic of social innovation, whereas the areas of interest are the most diverse within the business and management area. In international journals, a strong tendency to publish papers related to technological themes was noted. In the initial analysis, we determined the journals that publish on social innovation, as shown in Table 2.

When analyzing the topics of interest of the International Journal of Technology Management, a journal that published seven of the analyzed papers, the issues that had a strong relationship with social innovation such as competitiveness, cooperation, globalization and relations between businesses and governments, innovation and new technologies, among others. Another important factor is that in 2010, the same journal published a Special Issue on Social Innovation, publishing nine papers on the subject. Six of those papers were identified through our search. 
BBR

14,4

391

Table 2. Journals covered

\begin{tabular}{lc}
\hline Journals & $\mathrm{n}$ \\
\hline International Journal of Technology Management & 7 \\
Journal of Business Ethics & 6 \\
Technovation & 3 \\
Technology Analysis Strategic Management & 2 \\
Academia Revista Latinoamericana de Administracion & 1 \\
Academy of Management Learning Education & 1 \\
Business Society & 1 \\
Culture and Organization & 1 \\
Entrepreneurship and Regional Development & 1 \\
Journal of Business Research & 1 \\
Journal of Public Policy Marketing & 1 \\
Organization Science & 1 \\
Service Business & 1 \\
Systems Research and Behavioral Science & 1 \\
Technological Forecasting and Social Change & 1 \\
Total papers & 29 \\
\hline
\end{tabular}

The Journal of Business Ethics published six papers on the subject. This may be related to its interest in discussing the ethical issues connected to business from a wide variety of methodological and disciplinary perspectives, examining moral aspects of production systems, consumption, marketing, advertising, social and economic accounting, labor relations, public relations and organizational behavior. Specifically, the December 2012, Volume 111, Number 3 issue was a special issue on social entrepreneurship in theory and practice. We identified two papers from that special issue related to the subject, which made connections among theories of social entrepreneurship and social innovation.

Besides identifying the journals in which the papers were published, we also observed forty-two different institutions, with none of them showing predominance. By analyzing the institutions, we were able to make an overview of the countries that are publishing more often on social innovation. Canada topped the list with nine authors, followed by the United States, with seven authors. Australia and England each appeared with four authors on the subject, followed by the Netherlands and Spain each with three authors. Italy and Scotland had two authors each that published on social innovation. Several other countries have also had authors publish on the subject: Austria, Colombia, Costa Rica, Denmark, Finland, France and Germany. We also analyzed the papers by year of publication, as shown in Table 3 .

It is observed that in 2010 a significant number of papers were published since it was the year of the special issue on social innovation in the International Journal of Technology Management. Another relevant factor is that in 2012 there was a notable growth of publications on the subject, which is not explained by a connection with special journals. Therefore, we may suggest that interest in the subject is growing.

\subsection{METHODOLOGICAL ASPECTS}

One of the contributions of this research is to analyze the methodological aspects used by the authors who have published on the subject of social innovation in the management field. Thus, the papers were classified by researchers following the guidelines of the mentioned authors, being grouped as shown in Table 4. 
Table 3. Period of international publication

\begin{tabular}{lccccccc}
\hline Year & $\mathrm{n}$ & Year & $\mathrm{N}$ & Year & $\mathrm{n}$ & Year & $\mathrm{n}$ \\
\hline 2006 & 1 & 2008 & 1 & 2010 & 10 & 2012 & 9 \\
2007 & 1 & 2009 & 4 & 2011 & 2 & 2013 & 1 \\
Total & 29 & & & & & & \\
\hline
\end{tabular}

SOURCE: Research data

Table 4. Synthesis of methodological aspects

\begin{tabular}{lccc}
\hline Methodological aspects & $\mathrm{n}$ & $\%$ within aspect & $\%$ of total \\
\hline Theoretical & & & \\
theoretical essay that builds or proposes a concept or construct & 2 & $20 \%$ & $36 \%$ \\
theoretical essay of current theory systematization & 8 & $80 \%$ & \\
Total theoretical papers & 10 & $100 \%$ & \\
Theoretical and empirical & & & $64 \%$ \\
Single case study & 4 & $22 \%$ & \\
Multiple case study & 10 & $56 \%$ & \\
Exploratory & 4 & $22 \%$ & $0 \%$ \\
Total Theoretical and empirical papers & 18 & $100 \%$ & $100 \%$ \\
Empirical & & & \\
Total empirical papers & 0 & $100 \%$ & \\
\hline Total & 28 & & \\
\hline
\end{tabular}

SOURCE: Research data

A predominance of theoretical and empirical papers with a qualitative approach is observed. Internationally, $61 \%$ of the items fit this profile. Multiple case studies method is the predominant method among empirical papers, analyzing more than one object, leading to improved research, allowing for comparison among the subjects studied. No article having a methodological design dedicated exclusively to the empirical model was identified. Analysis shows that theoretical papers represent $39 \%$ of the entire sample. In addition, the highest incidence is in the systematization of existing theory. Only two papers tried to build or propose a concept or construct.

When performing the analysis of the papers, we came across a new possibility of categorization and chose to aggregate it to the initially proposed classification. Papers that were identified as theoretical and empirical, with qualitative approach, but were not necessarily classified as case studies, were grouped in a new category called "exploratory." They have qualitative approach characteristics but aim to investigate and explore a research context not yet fully structured, not fitting a case study design, for instance.

These results corroborate Edmondson and McManus's (2007) findings on the importance of the adequacy of fitting methodology designs for field research in organization studies. The same authors classified research in three maturity levels - nascent, intermediate and mature - classifying the appropriate methodological approaches to each level of maturity of the theory. For theories at the "nascent" level, the methodological approach suggested is qualitative in order to inform or inspire future research on a new phenomenon.

Thus, research on social innovation has mostly utilized qualitative approaches due to the theory being in the process of evolving, with a need to be explored and consolidated. In this sense, Collis and Hussey (2009) indicate that exploratory research should be used when there are few or no previous studies on the subject to be investigated; thus, the focus should be to obtain insight into the subject area for a more thorough investigation at a later stage. This suggests that social innovation is a theory and a field of study in development. 
BBR

14,4

\section{DISCUSSION}

After analyzing the goals, theories and results of the literature, we reached a classification of five major areas of interest, namely (1) concepts, models and case studies that specifically address the theories of social innovation; (2) papers that have social responsibility as a major theory but that address social innovation as a synonym of social responsibility or a complement of it; (3) studies that focus primarily on the term social entrepreneurship but have social innovation as a synonym or a complement of it; (4) papers that present social innovation as a result of cross-sector partnerships (non-profit organizations and forprofit organizations); and, (5) papers that, despite having the term social innovation in the keywords and references, have no relation with social innovation.

Thus, we analyzed the papers by areas of interest, discussing the aim of the research and key findings. We classified eight papers in the first area, those that specifically address the theories of social innovation. One of the criticisms that we present on these papers is about the fragility that they show to talk about SI. Papers associated with this theme are analogies to social problems and how these are being solved out. However, few papers clearly show the relationship of the term applied to the empirical cases. Incidentally, this has been one of constant criticism on this new field. Even though significant advances have not been identified, we present the main contributions of each of the papers analyzed in this area.

Linton (2009) considers the major motivator of his study as the great diversity of definitions of the term "innovation." That is, the author presents concepts and authors that lead to building a framework that enable the field to better analyze the impact of technological innovation and social innovation through a clarification of its inputs and outputs, and units and levels of analysis.

Fink, Lang and Harms (2013) investigate the restructuring of the local economy in rural areas that are affected by disruptive technologies. Relying on an institutional framework, the authors apply a multiple case study in two rural communities of Austria. The authors seek to identify practices that are crucial for the sustainable development of local communities and find that disruptive technologies must be accompanied by social innovations in the affected communities, since the capabilities and local community needs must be met and then to establish vertical links in regional and national policies.

Witkamp, Raven, and Royakkers, (2011) analyze the applicability of the concept strategic niche management (SNM) in social innovations. The concept arises from technological radical innovation, but the authors present an alternative to social entrepreneurship, seen as a new business model, which includes a business mindset while creating social value. The main conclusion presented focuses on the assertion that SNM can be adopted in radical social innovations since it is considered to be in the early stages of a social innovation project.

In an exploratory study, Lettice and Parekh (2010) aim to understand the process of social innovation, and to explore the lessons that can be transferred from the innovation theories of the business environment. The authors conducted interviews with ten UK innovators who have created solutions to social problems that were initially seen as remote and unlikely to go well, in areas ranging from job creation for the homeless to the manufacture of electric cars.

Simms (2006) approaches technical and social innovations as relatively new in human history. The article begins by relating that before the innovation, human behavior can be described and quantified with the same determinants of the behavior of other living systems. Thus, he suggests that technical and social innovations are key determinants of civilized human beings. Moreover, he purports that innovations cause changes in previously identified determinants for individuals and groups. 
Maak and Stoetter (2012) report one of the world's most important cases of social innovation, the Fundación Paraguaya, located in Paraguay, a country known for its longstanding struggle with corrupt governments. The authors studied the case of the first and oldest non-governmental organization of Paraguay. Despite the foundation's success being the result of a team effort, its remarkable development can be attributed in large part to Martin Burt, founder and chief executive.

Weber (2012) developed an article that has as its central focus an interview with author Frances Westley, considered one of the main authors in the area of management and who has devoted special attention to social innovation for many years. The article emphasizes (1) the importance of clear definitions in emerging areas of research and programming, (2) the nature (sometimes not obvious) of adaptations necessary to co-opt or redirect, and (3) the importance of unusual partnerships in order to make innovative things happen.

Bouchard (2012) makes an interesting initial thought, considering the renewed interest in the social economy that has arisen over the past decades, especially in relationship to the employment crisis and the renovation of state interventions. The social economy plays an important role in solving new social problems with innovative solutions, especially in the public services, making it important to better understand its innovative function. The article discusses the concept of social innovation and explains how it can be used as a framework for understanding the social economy. The author uses the case of Quebec on housing as an example of social economy to illustrate this proposition.

Thus, among the main contributions and advances of these papers are the attempt to develop the concept of SI, with the use of case studies and the development of conceptual frameworks. It is also noted the importance of a leader or social organization that actively participate in the social innovations. This contribution is important for the development of the field, as numerous studies have shown concern about how different actors with complementary objectives can contribute to the development of the SI initiatives. Incidentally, this is a subject in which the field must advance, identifying which are the actors involved and what the different relationships they play in SI initiatives.

Thus, the collaborative aspect of the SI is one of the possibilities of new studies which may occur seek to understand how the relationships between these actors. In particular, try to understand how internal actors are involved in the process of social innovation, since social innovation "are developed 'with' and 'by' users and not delivered 'to' and 'for' them. They can be identified by the type of relationships create among their beneficiaries" (CAULIER-GRICE et al., 2012, p. 21).

Another contribution is to identify the social innovation process and key partners for the development of social economy. This is another important issue for the development of the field, to identify the SI is the result of a systemic process that requires constant changes and therefore, adaptations and new solutions. Moreover, this process is an empowerment of the people who develop capacity to act (MOULAERT et al., 2005; BEPA, 2010).

Regarding the second area of interest, we classified two papers as having social responsibility as the main theory but address social innovation as a synonym or a complementary theory.

Spena and Chiara's article (2012) has as its central theme corporate social responsibility and its connection with social innovation, by identifying the process of creating value in networks and relational processes. With a multiple case study in three companies (Timberland, Herman Miller and Mattel), the authors highlight the innovative management patterns that create greater opportunities for companies that perform actions of social responsibility and their social partners.

Hanke and Stark (2009) attribute as the central theme of their article the concepts of Corporate Social Responsibility and Corporate Citizenship as important theories on ethics and the role of organizations in corporate behavior within civil society. The article raises the 
BBR

14,4

discussion about the reasons that lead companies to socially responsible action, suggesting a framework from the point of view of the development of meaning and legitimacy in the perspective of the corporate culture, social innovation and civil society.

We classified four papers in the third area of interest, which focuses primarily on the term social entrepreneurship but have social innovation as a synonym or as a complementary theory.

Dacin, Dacin and Tracey (2011) propose to identify the agenda of publications on social entrepreneurship. It is important to note that the authors present the term social entrepreneurship as an area covering a number of theoretical fields, including social innovation and the management of nonprofit organizations. The article introduces a number of questions about the field of study and classifies it as an emerging one. The study also identifies that scholars are trying to develop research questions and research paths. As research opportunities, the authors present five issues: institutions and social movements, networks, culture, identity and image, and cognition.

For Perrini, Vurro and Costanzo (2010), the central point is social entrepreneurship as a process to explore innovation to complex social problems. The authors present a theoretical model that addresses the process characteristics and dimensions involved in social entrepreneurship such as social-entrepreneurial opportunities identified, evaluated and employed with consistency among individual, organizational and contextual elements.

Dees (2012) present a theoretical essay on the two different types of culture that permeate social entrepreneurship: the ancient culture of "charity" and a more current culture that aims to solve social problems. The author presents the concepts around the topic and establishes that both cultures can contribute to the development of social entrepreneurship. However, the contribution will depend on the actors involved in the development of action strategies that address the integration of the values of each of these cultures.

Weerawardena and Mort (2012) show that social entrepreneurship has attracted a growing body of research in trying to understand the basis for creating successful value designed to solve social problems. In an effort to advance social entrepreneurship research beyond its current focus their article discusses the role of innovation to achieve greater social impact. Using several case studies, the research concludes that the competitive strategies of nonprofit organizations based on social innovation contribute substantially to the achievement of social value.

An important issue to note in this topic is the relationship between the concepts of social innovation and social entrepreneurship. Many authors have come to understand that the two terms can be seen as synonyms, however, we believe that social innovation should be seen as a process in which the social entrepreneur could be a change agent. It is known that two fields have been studying these concepts, and the field of entrepreneurship is more concerned with the personal characteristics of the agent that promotes these social changes. And the field of innovation is concerned with the context in which this initiative is going, the process, the actors involved and the social problems that these initiatives are addressing. Thus, we understand in the same sense that European Commission (2013), that are different levels of analysis to observe the same phenomenon: a micro level, which analyzes the individual; and a macro level, which analyzes the process. To understand a third level, meso, we can analyze the relationships that occur between social organizations, such as the papers covered in the fourth area.

We classified six papers in the fourth area of interest: social innovation as a result of cross-sector partnerships (non-profit organizations and for-profit organizations).

Le Ber and Branzei (2010) analyze the relational processes that support social innovation in cross-sector strategic partnerships. The authors use four case studies 


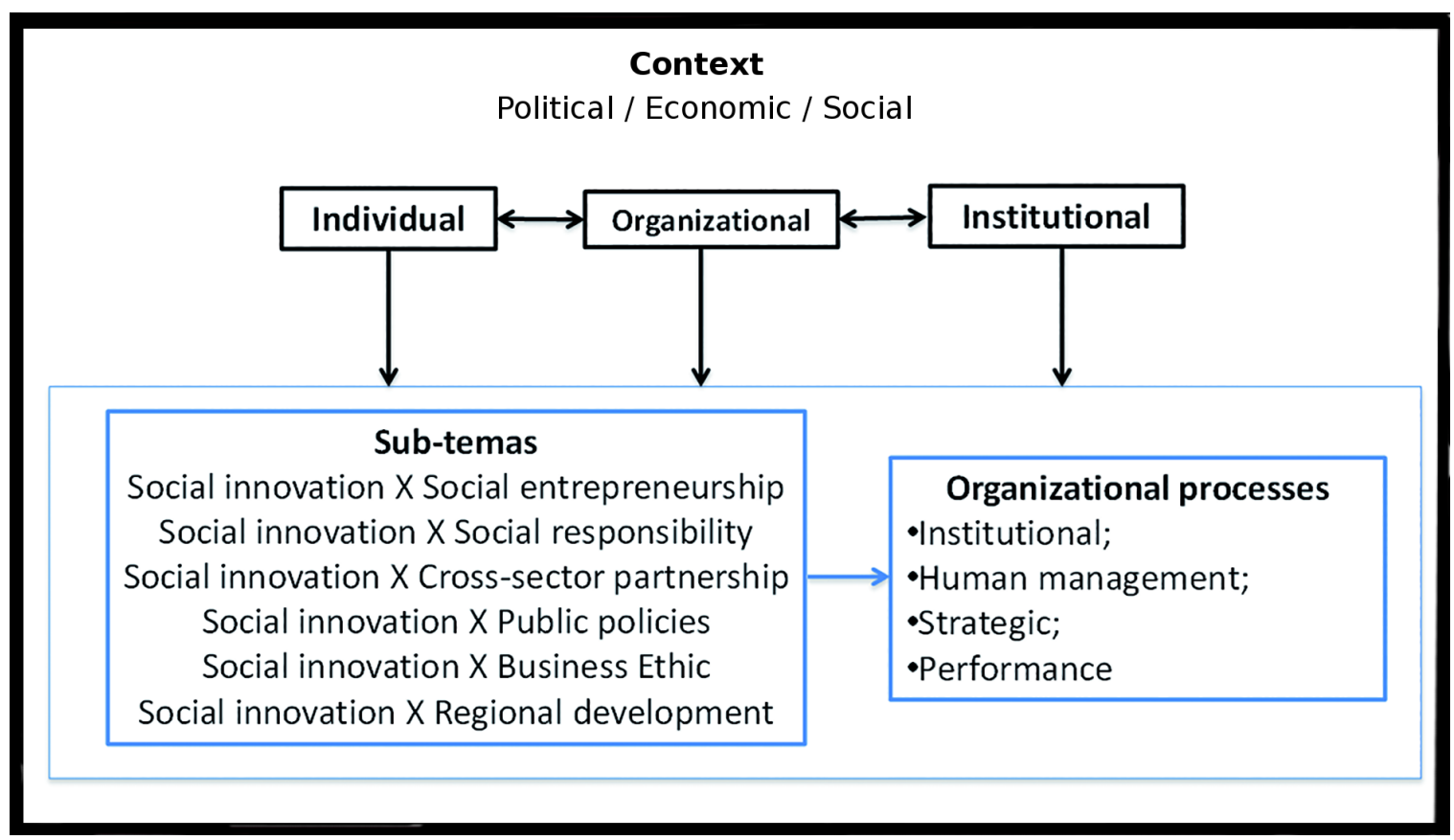

Figure 1. Framework for future research on social innovation. SOURCE: Authors of this study

to understand the duality of success and failure in relationships between for-profit and non-profit organizations. As the main contribution, the authors present a framework that models how organizations may keep up with the success or overcome temporary failures. In a complementary study published in another journal, the same authors begin the analysis by pointing out that partnerships between for-profit and non-profit organizations often have large incompatibilities, mainly on the confrontation between values and identities of the organizations belonging to different sectors of the economy. Thus, organizations are developing social value as they mature the partnership. Therefore, the main contribution of the paper is related to a framework that addresses four phases of cross-sector partnership: negotiation, elasticity, plasticity and fusion (LE BER; BRANZEI, 2010).

Selsky and Parker (2010) also address the central theme of cross-sector social partnerships (CSSPs) that produce benefits at individual, organizational, sectorial and social levels. The authors begin with the definition of platforms for social partnerships developed in previous studies and set them as ways for constructing meaning in the projects, drawing attention to certain desired characteristics or other underestimated resources. The three platforms are identified as the resource dependence platform, social issues platform, and platform of the social sector.

Raufflet (2009) analyzes the experience of so-called "Post-secondary education" at a university in South Africa, realizing that this education model may be a viable solution to an existing social problem in developing countries. The author presents two contributions: the first related to the proposed educational model, and the second to the creation of partnerships within the business sector.

Austin et al. (2009) present an important contribution that tries to approximate the nonprofit organization to for-profit ones. The authors indicate that although non-profit and for-profit organizations are more connected than ever, they still have many differences. Companies must continue to play their fundamental economic functions efficiently because they are the engines of a healthy economy. Note, also, that this same article was published in a leading journal on social innovation in 2007, the Stanford Social Innovation Review. 
BBR

14,4

It is considered that the identification of this area was important to understand how these items help the field of SI in understanding of the relationship management and the characteristics of the relationship between for-profit and nonprofit organizations. Usually, this combination is not carried out studies in SI, but the cross-sector studies may be important to understand the process of social innovation, since most of the initiatives reported in studies include different actors, such as companies, NGOs, communities, associations, etc.

To corroborate this issue, there is the definition of Cloutier (2003) that checks on social innovation cooperation between a variety of actors as a process of collective learning and knowledge creation. This process requires the participation of beneficiaries in different degrees of the creation and implementation of social innovation.

Finally, we classified three papers in the fifth area of interest: those papers that, despite having the term social innovation in the keywords and references, have no relation at all with social innovation concept. Menzel, Aaltio and Ulijn (2007) present a theoretical essay on intrapreneurship; Carnera (2012) conducts a theoretical paper on the ambivalence of topics such as "biopolitics," developed by Michael Foucault, and the "modern labor and management"; and Linton (2008) makes a critical analysis of the reasons why obtaining funding for scientific research is increasingly difficult for many public and private labs.

\section{PROPOSAL FOR A FRAMEWORK FOR FUTURE RESEARCH: THE TRENDS TO SI}

Based on our analysis of the papers, we identified that more studies are needed on social innovation because unanimity among scholars in the field on the concept and theme features does not exist so far. A diversity of understandings on the subject pervades the field. Consequently, we present a framework, as shown in Figure 1, with possible subthemes of interest, research contexts, analytical lenses and organizational processes to be investigated.

The theme can be analyzed considering the different social, political or economic contexts and by using different analytical lenses.

For analysis of the context in which social innovation initiatives develop it is important to understand factors such as the political, social and economic systems (MATTEN; MOON, 2008; WHITLEY, 1999; TRANSIT, 2015). These factors are important as the reasons that influence the development, creation and maintenance of an SI. The pressure on the political and economic factors may explain why communities seek social innovations, since often innovations are related to high rates of poverty and problems linked to education, health and employment. Economic and structural crises enable communities to seek alternatives that are not only linked to the aid of the government. Thus, understanding the environment and social conditions are fundamental in order to understand SI initiatives.

In a second level of the framework, we propose a distinction between levels of analysis. Considering the previous literature, especially those related to differences between the perspectives of social innovation and social entrepreneurship, as well as the different levels of analysis that these differences allow observe, we have identified three levels: individual, organization or institution (a more systemic perspective). This view was supported by references to European Commission (2013), Phills Jr., Deiglmeier and Miller (2008) and Westall (2007).

Based in the literature review and a systematic review of papers, six sub-themes that may be related to social innovation were identified and may be studied in specific organizational processes, such as institutional theories, human resources management, strategy and performance. Our frame makes no claim to be exhaustive. Other aspects may be identified that may assist in the consolidation of this theme and should be explored in future research. 


\section{FINAL CONSIDERATIONS}

Social innovation is an essential process for the evolution of society and the search for sustainable alternatives for the collective well being. In a sense, the observation of different research contexts on social innovation allows future researchers to use this study to identify new opportunities to the area in order to identify and/or constitute economic and social mechanisms for the growth of organized communities in a democratic society.

This study achieved its main objective by analyzing the aspects that characterize the research in this new form of innovation. In regard to the first specific objective, this research presented an analysis of the 29 papers from research in databases on the theme social innovation, and a diversity of journals and authors who have published on the subject was identified, since papers were indexed from 15 different journals. Furthermore, the research on this new innovation area covers a very wide range of institutions and nationalities; the authors are linked to 42 institutions, distributed in 15 countries. Thus, a predominance of a group of researchers, as in other areas of more consolidated knowledge, is observed.

Furthermore, the journals in which future research might be directed to publish on social innovation were identified. Multidisciplinary studies on the subject in mainstream journals were located, presenting an important contribution to research in this area.

In the analysis on the methodologies most used in the field of social innovation, a significant number of papers were found that have the theoretical and empirical methodological profile of a qualitative approach, with mostly case studies used to support the theories proposed. According to the sample of papers, the studies may evolve into hybrid research (qualitative and quantitative), enabling the advancement of the theory studied (EDMONDSON; MCMANUS, 2007). Thus, future research might begin the search for constructs and variables for quantitative research.

In addition, we analyzed the main results and objectives of the analyzed papers, coming to a rating of five major areas of interest. In particular, the main themes are focused on the central concepts of social innovation and its relationship with social entrepreneurship, social responsibility and cross-sector partnerships. These related concepts are sometimes used as synonyms, but there is a need to provide more robust empirical data in order to distinguish these concepts. Another contribution is the identification of sub-topics, contexts, actors and organizational processes for future research in a framework. Some of these sub-topics and unit of analysis might prevail in management research in the long term. Further research could look at the incipient research published from Brazilian researchers to analyze how the sub-topics have being used in the national context.

Thus, new theoretical perspectives have been identified for future studies to deepen the field. The main approaches that can yield future studies are: social movement theories; theory of transformative change; power and the multi-actor perspective; institutional theory; and, structuration theory.

Some questions/propositions could be raised for further studies. To analyze the first level of the framework, relating to the context, we propose: a) The context influences the SI, how and to what extent? b) How is the interference of political, economic and social factors in SI initiatives? c) Are there differences in SI initiatives in different social contexts?

To analyze the second level, referring to the level of analysis, we propose: d) How different actors act in SI initiatives? e) What is the role of institutions in SI? f) How organizations behave in SI initiatives?

And finally, to relate the SI with other areas of knowledge, we propose: d) How are the cross-sectors partnerships in SI initiatives? e) What is the role of social entrepreneur as part of the SI process? f) Power relations in SI. g) What is the role of networks to form SI initiatives? h) The scale and path dependence in SI. 
BBR

14,4

In conclusion, despite the diversity of concepts and identified contexts, the theory in social innovation may generate significant value for the development of social alternatives, including an impact that may generate innovative actions for the development of those involved. In an emerging country such as Brazil, management academics as well as entrepreneurs should pay attention to the evolution and application of social innovation.

\section{REFERENCES}

AUSTIN, J. E. et al. Capitalizingonconvergence. Academia-Revista Latinoamericana De Administracion, n. 43, p. 93-106, 2009. ISSN 1012-8255.

BEPA-Bureau of European Policy Advisers. Empowering people, driving change: Social innovation in the European Union, Luxembourg: Publications Office of the European Union. 2010.

BHATT, P.; ALTINAY, How social capital is leveraged in social innovations under resource constraints? Management Decision, v. 51, n. 9, p. 1772-1792, 2013.

BIGNETTI, Luiz Paulo. As inovações sociais: uma incursão por idéias, tendências e focos de pesquisa. Revista das Ciências Sociais, São Leopoldo, v. 47, n. 1, p. 3-14, jan./abr. 2011.

BOUCHARD, M. J. Social innovation, an analytical grid for understanding the social economy: the example of the Quebec housing sector. Service Business, v. 6, n. 1, p. 47-59, Mar 2012. ISSN 1862-8516.

CAJAIBA-SANTANA, G. Social innovation: Moving the field forward. A conceptual framework. Technological Forecasting and Social Change, v. 82, p. 42-51, 2014.

CALDAS, M.; TONELLI, M.; LACOMBE, B. Espelho, espelho meu: Metaestudo da Produção científica em Recursos Humanos nos ENANPADs da década de 90. In: XXVI Encontro da ANPAD. Anais ... 2002. Online: $\quad$ http://www.anpad.org.br/diversos/trabalhos/EnANPAD/enanpad_2002/GRT/GRT1976.pdf.. Aces: 17 July 2013.

CARNERA, A. The affective turn: The ambivalence of biopolitics within modern labour and management. Culture and Organization, v. 18, n. 1, p. 69-84, 2012. ISSN 1475-9551.

CAULIER-GRICE, J., DAVIES, A., PATRICK, R., \& NORMAN, W. Defining social innovation. A deliverable of the project: "The theoretical, empirical and policy foundations for building social innovation in Europe"(TEPSIE), European Commission - 7th Framework Programme, Brussels: European Commission, DG Research, 2012.

CLEMENTS, M. D. J.; SENSE, A. J. Socially shaping supply chain integration through learning. International Journal of Technology Management, v. 51, n. 1, p. 92-105, 2010. ISSN 0267-5730.

CLOUTIER, J. Qu'est ce que l'innovation sociale? [s.l: s.n.]. v. ET0314

COLLIS, Jill; HUSSEY, Roger. Pesquisa em administração: um guia prático para alunos de graduação e pósgraduação. 2. ed. Porto Alegre: Bookman, 2005.

CRISES - Centre de recherchesur les innovations sociales. ANDREW, Caroline; KLEIN, Juan-Luis. Social Innovation: What is it and why is it important to understand it better. Online: <http://www.crises.uqam.ca/ upload/files/publications/etudes-theoriques/CRISES_ET1003.pdf>. Aces: 20 July 2013.

CSI - Centre for social innovation. Social innovation. Online: <http://socialinnovation.ca/about/socialinnovation>. Aces: 20 July 2013.

DACIN, M. T.; DACIN, P. A.; TRACEY, P. Social Entrepreneurship: A Critique and Future Directions. Organization Science, v. 22, n. 5, p. 1203-1213, Sep-Oct 2011. ISSN 1047-7039.

DAWSON, P.; DANIEL, L. Understanding social innovation: a provisional framework. International Journal of Technology Management, v. 51, n. 1, p. 9-21, 2010. ISSN 0267-5730.

DEES, J. G. A Tale of Two Cultures: Charity, Problem Solving, and the Future of Social Entrepreneurship. Journalof Business Ethics, v. 111, n. 3, p. 321-334, Dec 2012. ISSN 0167-4544.

DRUCKER, Peter F. Inovação e espírito empreendedor. Tradução de Carlos Malferrari. São Paulo: Pioneira Thomson, 2002.

EBSCO Information Service and EBSCO Publishing. Online: <http://ehis.ebscohost.com/eds/search/ basic?sid=af225d86-9501-4b5b-b7b7-8e409e7c31c2\%40sessionmgr111\&vid=1\&hid=105>. Aces: 16 July 2013.

EDMONDSON, A. C.; MCMANUS, S. E. Methodological fit in management field research. Academy of Management Review, v. 32, n. 4, p. 1155-1179, 2007.

EUROPEAN COMMISION. Social innovation research in the European Union: Approaches, findings and future directions. Policy Review. Luxembourg: Publications Office of the European Union, 2013. 
FARFUS, Daniele. Empreendedorismo social e desenvolvimento local: um estudo de caso no SESI Paraná. Curitiba: UNIFAE, 2008. Dissertação (Mestrado em Organizações e Desenvolvimento), Centro Universitário Franciscano do Paraná, 2008.

FINK, M.; LANG, R.; HARMS, R. Local responses to global technological change - Contrasting restructuring practices in two rural communities in Austria. Technological Forecasting and Social Change, v. 80, n. 2, p. 243-252, Feb 2013. ISSN 0040-1625.

GOLPADAS, A. Creating firm, customer, and societal value: Toward a theory of positive marketing. Journal of Business Research, v. 68, n. 12, p. 2446-2451, 2015.

HANKE, T.; STARK, W. Strategy Development: Conceptual Framework on Corporate Social Responsibility. Journal of Business Ethics, v. 85, p. 507-516, Apr 2009. ISSN 0167-4544.

HOWALDT, Jürgen; SCHWARZ, Michael. Social Innovation: Concepts, research fields and international trends. Online: <http://www.sfs-dortmund.de/odb/Repository/Publication/Doc\%5C1289\%5CIMO_ Trendstudie_Howaldt_Schwarz_englische_Version.pdf $>$. Aces: 20 October 2012.

INTERNATIONAL JOURNAL OF TECHNOLLGY MANAGEMENT. Online: $<$ http://www.inderscience. com/jhome.php?.jcode=ijtm>. Aces: 21 July 2013.

JENNER, Caroline. Business and Education: Powerful Social Innovation Partners. Stanford Social Innovation Review. Online: $\quad<\mathrm{http} / / / \mathrm{www}$. ssireview.org/blog/entry/business_and_education_powerful_social_ innovation_partners>. Aces: 20 October 2012.

JOURNAL OF BUSINESS ETHICS. Online: <http://www.springer.com/social+sciences/applied+ethics/ journal/10551>. Aces: 21 July 2013.

KINDER, T. Social innovation in services: technologically assisted new care models for people with dementia and their usability. International Journal of Technology Management, v. 51, n. 1, p. 106-120, 2010. ISSN 0267-5730.

KLEIN, J. L.; TREMBLAY, D. G.; BUSSIERES, D. R. Social economy-based local initiatives and social innovation: a Montreal case study. International Journal of Technology Management, v. 51, n. 1, p. 121138, 2010. ISSN 0267-5730.

LE BER, M. J.; BRANZEI, O. (Re)Forming Strategic Cross-Sector Partnerships Relational Processes of Social Innovation. Business \& Society, v. 49, n. 1, p. 140-172, Mar 2010a. ISSN 0007-6503.

. Value Frame Fusion in Cross Sector Interactions. Journal of Business Ethics, v. 94, p. 163-195, 2010b. ISSN 0167-4544.

LETTICE, F.; PAREKH, M. The social innovation process: themes, challenges and implications for practice. International Journal of Technology Management, v. 51, n. 1, p. 139-158, 2010. ISSN 0267-5730.

LINTON, J. D. Why big science has trouble finding big money and small science has difficulties finding small money. Technovation, v. 28, n. 12, p. 799-801, Dec 2008. ISSN 0166-4972.

. De-babelizing the language of innovation. Technovation, v. 29, n. 11, p. 729-737, Nov 2009. ISSN 0166-4972.

MAAK, T.; STOETTER, N. Social Entrepreneurs as Responsible Leaders: 'FundacinParaguaya' and the Case of Martin Burt. Journal of Business Ethics, v. 111, n. 3, p. 413-430, Dec 2012. ISSN 0167-4544.

MATTEN, D.; MOON, J. "Implicit" and "Explicit" CSR: A Conceptual Framework for a Comparative Understanding of Corporate Social Responsibility. Academy of Management Review, v. 33, n. 2, p. 404424, 1 abr. 2008.

MOULAERT, F., MARTINELLI, F., SWYNGEDOUW, E., \& GONZÁLES, S. Towards alternative model(s) of local innovation. Urban Studies, v. 42, n. 11, p. 1969-1990, 2005

MCLOUGHLIN, I.; PREECE, D. 'Last orders' at the rural 'cyber pub': a failure of 'social learning'? International Journal of Technology Management, v. 51, n. 1, p. 75-91, 2010. ISSN 0267-5730.

MENZEL, H. C.; AALTIO, I.; ULIJN, J. M. On the way to creativity: Engineers as intrapreneurs in organizations. Technovation, v. 27, n. 12, p. 732-743, Dec 2007. ISSN 0166-4972.

MULGAN, Geoff et al. Social innovation: what it is, why it matters and how it can be accelerated. London: The Young Foundation, 2007. Online: < http://youngfoundation.org>. Aces: 20 July 2013.

MURPHY, M.; PERROT, F.; RIVERA-SANTOS, M. New perspectives on learning and innovation in crosssector collaborations. Journal of Business Research, v. 65, n. 12, p. 1700-1709, Dec 2012. ISSN 01482963.

O’BYRNE, L.; MILLER, M.; DOUSE, C.; VENKATESH, R.; KAPUCU, N. Social innovation in the public sector: The case of Seoul metropolitan government. Journal of Economic and Social Studies, Vol. 4, No. 1, pp. 53-71, 2014. 
BBR

14,4

OECD. Proposed guidelines for collecting and interpreting technological innovation data: Oslo manual 2. ed. Paris: Organisation for Economic Co-Operation and Development - OECD, 1997. Traduced: Finep, 2004.

PERRINI, F.; VURRO, C.; COSTANZO, L. A. A process-based view of social entrepreneurship: From opportunity identification to scaling-up social change in the case of San Patrignano. Entrepreneurship and Regional Development, v. 22, n. 6, p. 515-534, 2010. ISSN 0898-5626.

PHILLS JR, J. A.; DEIGLMEIER, K.; MILLER, D. T. Rediscovering Social Innovation. STANFORD SOCIAL INNOVATION REVIEW, v. Fall, p. 34-43, 2008.

RAUFFLET, E. Mobilizing Business for Post-Secondary Education: CIDA University, South Africa. Journal of Business Ethics, v. 89, p. 191-202, Nov 2009. ISSN 0167-4544.

RODRIGUES, Andréa Leite. Modelos de gestâo e inovação social em organizações sem fins lucrativos: um estudo comparativo de casos no Brasil e no Québec. São Paulo: FGV, 2004. Tese (Doutorado em Administração de Empresas), Escola de Administração de Empresas de São Paulo da Fundação Getulio Vargas, 2004.

SCHUMPETER, Joseph A. A Teoria do desenvolvimento econômico: uma investigação sobre lucros, capital, crédito, juro e ciclo econômico. São Paulo: Nova Cultural, 1985.

SELSKY, J. W.; PARKER, B. Platforms for Cross-Sector Social Partnerships: Prospective Sensemaking Devices for Social Benefit. Journal of Business Ethics, v. 94, p. 21-37, 2010.

SILVA, Silvio Bitencourt da. Inovação Social: um estudo preliminar sobre aprodução acadêmica entre 2001 e 2011. In: AnaisConvibra, 2011. Online: <http://www.convibra.com.br/upload/paper/adm/adm_2597.pdf>. Aces: 27 October 2012.

SILVA, T. N.; MAURER, A. M. Analytical Dimensions for Identifying Social Innovations: evidence from collective enterprises. Brazilian Business Review v. 11, p. 123-145, 2014.

SIMMS, J. R. Technical and social innovation determinants of behaviour. Systems Research and Behavioral Science, v. 23, n. 3, p. 383-393, May-Jun 2006. ISSN 1092-7026.

SIQUEIRA, Marli Aparecida da Silva. Monografias e teses: das normas técnicas ao projeto de pesquisa. Brasília: Consulex, 2005.

SMITH, I. H.; WOODWORTH, W. P. Developing social entrepreneurs and social innovators: A social identity and self-efficacy approach. Academy of Management Learning \& Education, Vol. 11, No. 3, pp. 390-407, 2012.

SPENA, T. R.; DE CHIARA, A. CSR, innovation strategy and supply chain management: toward an integrated perspective. International Journal of Technology Management, v. 58, n. 1-2, p. 83-108, 2012. ISSN $0267-$ 5730.

TARDIF, C.;HARRISSON, D. Complémentarité, convergence et transversalité: la conceptualisation del'innovationsociale au CRISES, in CRISES. Centre de Recherche Sur Les Innovations Sociales. Cahiers du CRISES. Québec, 2005.

TAYLOR, J. B. Introducing Social Innovation. The Journal of Applied Behavioral Science, v. 6, n. 1, p. 69-77, 1970.

TRANSIT - Transformative Social Innovation Theory.TRANSIT WP3 deliverable D3.2 - “A first prototype of TSI theory", 2015. Online: http://www.transitsocialinnovation.eu/content/original/Book\%20covers/ Local\%20PDFs/161\%20TRANSIT\%20WP3\%20deliverable\%20D3.2\%20of\%2030\%2004\%202015\%20 v1.1(1).pdf. Aces: 12 Mars 2016.

VARADARAJAN, R. Toward Sustainability: Public policy, global social innovations for base-of-the-pyramid markets, and marketing for a better world. Journal of International Marketing, Vol. 22, No. 2, pp. 1-20, 2014.

VERGRAGT, P. J.; BROWN, H. S. The challenge of energy retrofitting the residential housing stock: grassroots innovations and socio-technical system change in Worcester, MA. Technology Analysis \& Strategic Management, v. 24, n. 4, p. 407-420, 2012. ISSN 0953-7325.

WEBER, J. M. Social Innovation and Social Enterprise in the Classroom: Frances Westley on Bringing Clarity and Rigor to Program Design. Academy of Management Learning \& Education, v. 11, n. 3, p. 409418, Sep 2012. ISSN 1537-260X.

WEERAWARDENA, J.; MORT, G. S. Competitive Strategy in Socially Entrepreneurial Nonprofit Organizations: Innovation and Differentiation. Journal of Public Policy \& Marketing, v. 31, n. 1, p. 91101, Spr 2012. ISSN 0743-9156. 
WESTALL, A. How can innovation in social enterprise be understood, encouraged and enabled? UKCabinet Office, Office of The Third Sector, , 2007. Disponível em: <http://webarchive.nationalarchives.gov.uk/+/ http:/www.cabinetoffice.gov.uk/upload/assets/www.cabinetoffice.gov.uk/third_sector/innovation_social_ enterprise.pdf>

WHITLEY, R. Divergent capitalisms: The social structuring and change of business systems. Oxford: Oxford University Press., 1999.

WITKAMP, M. J.; RAVEN, R.; ROYAKKERS, L. M. M. Strategic niche management of social innovations: the case of social entrepreneurship. Technology Analysis\&Strategic Management, v. 23, n. 6, p. 667-681, 2011. ISSN 0953-7325.

YIN, R. K. Estudo de caso: planejamento e métodos. 3. ed. Porto Alegre: Bookman, 2005. 